\title{
Dodecylamine Derivative of Hydroxocobalamin Acts as a Potent Inhibitor of Cobalamin-Dependent Methionine Synthase in Mammalian Cultured COS-7 Cells
}

\author{
Tomohiro Bito $^{1 *}$, Mariko Yasui ${ }^{2}$, Toshio Iwaki ${ }^{3}$, Yukinori Yabuta ${ }^{1}$, Tsuyoshi Ichiyanagi', \\ Ryoichi Yamaji ${ }^{2}$, Yoshihisa Nakano ${ }^{2,4}$, Hiroshi Inui ${ }^{2,3}$, Fumio Watanabe ${ }^{1 \#}$ \\ ${ }^{1}$ Division of Applied Bioresources Chemistry, The United Graduate School of Agricultural Sciences, Tottori \\ University, Tottori, Japan \\ ${ }^{2}$ Division of Applied Biological Chemistry, Graduate School of Life and Environmental Sciences, Osaka \\ Prefecture University, Sakai, Japan \\ ${ }^{3}$ Department of Clinical Nutrition, Osaka Prefecture University, Habikino, Japan \\ ${ }^{4}$ Department of Life Science, Osaka Women's Junior College, Fujiidera, Japan \\ Email: "watanabe@muses.tottori-u.ac.jp
}

Received 26 May 2014; revised 30 June 2014; accepted 15 July 2014

Copyright $(02014$ by authors and Scientific Research Publishing Inc.

This work is licensed under the Creative Commons Attribution International License (CC BY).

http://creativecommons.org/licenses/by/4.0/

(c) (i) Open Access

\begin{abstract}
We evaluated whether the dodecylamine derivative of hydroxocobalamin acts as a potent inhibitor of cobalamin-dependent enzymes in an African green monkey kidney cell, COS-7. When the dodecylamine derivative $(1.0 \mu \mathrm{mol} / \mathrm{L})$ did not show any cytotoxicity in the cultured cells, the derivative could not affect methylmalonyl-CoA mutase (holo-enzyme) activity, but significantly inhibit methionine synthase (holo-enzyme) activity in the cell homogenates of COS-7 grown in 1.0 $\mu \mathrm{mol} / \mathrm{L}$ hydroxocobalamin-supplemented medium. An immunoblot analysis indicated that the dodecylamine derivative could not decrease the protein level of methionine synthase, but significantly inhibit the enzyme activity.
\end{abstract}

\section{Keywords}

Dodecylamine Derivative, Cobalamin, COS-7 Cell, Enzyme Inhibitor, Hydroxocobalamin

\footnotetext{
*A research fellow of Japan society for the promotion of science.

\#Corresponding author.

How to cite this paper: Bito, T., Yasui, M., Iwaki, T., Yabuta, Y., Ichiyanagi, T., Yamaji, R., Nakano, Y., Inui, H. and Watanabe, F. (2014) Dodecylamine Derivative of Hydroxocobalamin Acts as a Potent Inhibitor of Cobalamin-Dependent Methionine Synthase in Mammalian Cultured COS-7 Cells. Food and Nutrition Sciences, 5, 1318-1325. 


\section{Introduction}

Cyanocobalamin (or vitamin $\mathrm{B}_{12}$, $\mathrm{Cbl}$ ) is an essential nutrient for humans, which have a complex process for gastrointestinal absorption of dietary Cbl [1] [2]. The Cbl released from food protein is bound to haptocorrin (salivary Cbl-binding protein) and then intrinsic factor (IF, gastric Cbl-binding protein) in the proximal ileum. The IF-Cbl complex can enter mucosal cells in the distal ileum by receptor-mediated endocytosis and thereafter the $\mathrm{Cbl}$ absorbed is bound to transcobalamin II to circulate in blood. After being taken up by the target cells, Cbl is converted into the two coenzyme forms, 5'-deoxyadenosylcobalamin and methylcobalamin, which function as the coenzyme of methylmalonyl-CoA mutase (EC 5.4.99.2) [3] and methionine synthase (EC 2.1.1.13) [4], respectively.

The major signs of Cbl deficiency are megaloblastic anemia and neuropathy [5]. The underlying cause(s) of various symptoms (developmental disorder, metabolic abnormalities, and neuropathy) caused by Cbl deficiency are not still understood [6]. To investigate the molecular mechanisms of the metabolic disorders linked to such diseases, Cbl-deficient animal models are absolutely required. However, they cannot be readily prepared because animals (e.g. rats) must be fed with a Cbl deficient diet for long periods to make them Cbl-deficient [7]. The Cbl analogue with a modification of the side chain of C-ring, Cbl [c-lactam], has been reported to antagonize $\mathrm{Cbl}$ in the cultured HL 60 cells [8]. Subcutaneous administration of hydroxocobalamin (OH-Cbl) [c-lactam] to rats has indicated that the analogue has the ability to act as a potent inhibitor of the mammalian Cbl-dependent enzymes to make the rats Cbl-deficient [9]. However, considerably high concentration of OH-Cbl [c-lactam] must be administrated for several weeks with osmotic mini pumps in order to prepare Cbl-deficient rats because IF hardly binds $\mathrm{OH}-\mathrm{Cbl}$ [c-lactam] [9].

McEwan et al. [10] have demonstrated the preparation of ribose-5'-carbamate derivatives of Cbl; some of the alkylamine derivatives have considerably high affinity for IF. Our preliminary experiments indicate that the prepared alkylamine derivatives did not show any biological activity as $\mathrm{Cbl}$ in certain Cbl-requiring microorganisms. Remarkably they could inhibit significantly Cbl-dependent enzyme activities at the in vitro experiments. If the Cbl alkylamine derivatives act as potent inhibitors of mammalian Cbl-dependent enzymes in vivo, Cbl-deficient animals would be readily prepared by oral administration of the derivatives.

Here we described characterization of the Cbl alkylamine derivatives as potent inhibitors of the Cbl-dependent enzymes in the mammalian cultured cells.

\section{Materials and Methods}

\subsection{Materials}

CN-Cbl, 1,1'-carbonyldiimidazole, hexylamine, dodecylamine, and dexadecylamine were purchased from Wako Pure Chemical Industries (Osaka, Japan). OH-Cbl was obtained from Sigma (St. Louis, USA). Phenyl-Toyopearl 650M was purchased from TOSHO Corporation (Tokyo, Japan). An antibody for human methionine synthase (anti-MTR antibody) was obtained from Abcam ${ }^{\circledR}$ Japan (Tokyo, Japan).

\subsection{Preparation of Alkylamine Derivatives of $\mathrm{CN}-\mathrm{Cbl}$}

Alkylamine derivatives of CN-Cbl were prepared according to the method of McEwan et al. [10]. In briefly, solid 1,1'-carbonyldiimidazole (26 mg) was added to CN-Cbl ( $0.1 \mathrm{~g})$ which had been dissolved in dimethyl sulfoxide $(1.2 \mathrm{~mL})$ at $30^{\circ} \mathrm{C}$ and the mixture was stirred at $300 \mathrm{rpm}$ for $25 \mathrm{~min}$. Hexylamine, dodecylamine, or hexadecylamine (each at $0.27 \mathrm{mmol}$ ) was added to the mixture and then stirred at $300 \mathrm{rpm}$ for $24 \mathrm{~h}$ at a room temperature $\left(25^{\circ} \mathrm{C}\right)$ (Figure 1). Cbl compounds were extracted twice from the mixture with $2 \mathrm{~mL}$ of phenol/dichloromethane $(1: 2, \mathrm{v} / \mathrm{v})$ and then re-extracted twice from the combined phenol fractions with $2 \mathrm{~mL}$ of distilled water. The water-soluble fractions were combined and put on a column $(2.4 \times 24 \mathrm{~cm})$ of a TSK gel Phenyl-Toyopearl $650 \mathrm{M}$ which had been washed with $250 \mathrm{~mL}$ of $25 \%(\mathrm{v} / \mathrm{v})$ ethanol. Unmodified and modified CN-Cbl compounds were eluted with $250 \mathrm{~mL}$ of $25 \%(\mathrm{v} / \mathrm{v})$ and $60 \%(\mathrm{v} / \mathrm{v})$ ethanol solution, respectively. The product fractions were combined and evaporated under the reduced pressure and the residue was dissolved in $5 \mathrm{~mL}$ of $80 \%(\mathrm{v} / \mathrm{v})$ ethanol. Each product was further purified with silica gel 60 TLC as a solvent (1-butanol:2-propanol:water $=10: 7: 10, \mathrm{v} / \mathrm{v} / \mathrm{v}$ ). After the TLC sheet had been dried, each derivative was collected, extracted with $80 \%(\mathrm{v} / \mathrm{v})$ methanol solution, and evaporated to dryness under the reduced pressure. The residual fraction was dissolved in a small amount of $18 \%(\mathrm{v} / \mathrm{v})$ acetonitrile and then purified with a reversed-phase 


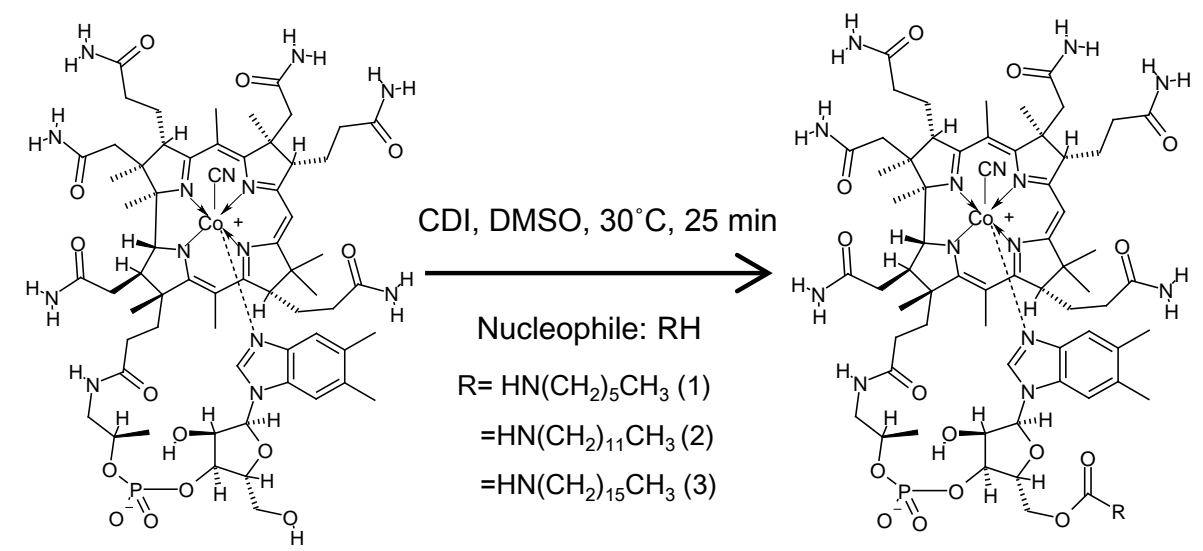

Figure 1. Summary of preparation of CN-Cbl alkylamine derivatives. CDI, 1,1'-carbonyldiimidazole; DMSO, dimethyl sulfoxide; and RH, hexylamine (1), dodecylamine (2), and hexadecylamine (3).

HPLC column (Wakosil-II5C18RS $\varphi 4.6 \times 150 \mathrm{~mm}$ ) using a Shimadzu HPLC apparatus (LC10 system, Kyoto, Japan). These CN-Cbl derivatives were eluted with a linear gradient of acetonitrile ( $18 \%-28 \%$ for $8.5 \mathrm{~min}$ and $28 \%-100 \%$ for $13 \mathrm{~min}$ ) at $40^{\circ} \mathrm{C}$ and monitored by measuring absorbance at $254 \mathrm{~nm}$. The flow rate was 1.0 $\mathrm{mL} / \mathrm{min}$. Each peak fraction was collected, evaporated to dryness under the reduced pressure, and used for the following experiments.

Hexylamine, dodecylamine, and hexadecylamine derivatives of $\mathrm{CN}-\mathrm{Cbl}$ were dissolved in distilled water and their concentrations were determined with $\lambda_{361}=(\varepsilon=10,500,16,900$ and 20,000 , respectively $)$ as described in the cited reference [10].

\subsection{Preparation of $\mathrm{CN}-\mathrm{Cbl}$ [c-Lactam]}

CN-Cbl [c-lactam] was prepared from CN-Cbl by the method as described previously [11].

\subsection{Preparation of Alkylamine and $c$-Lactam Derivatives of $\mathrm{OH}-\mathrm{Cbl}$}

The above alkylamine and $c$-lactam derivatives of $\mathrm{CN}$-Cbl were dissolved in $5.0 \mathrm{~mL}$ of distilled water and bubbled with $\mathrm{N}_{2}$ gas for 20 min and reduced with $\mathrm{NaH}_{4}$. Each treated solution was neutralized with $1.0 \mathrm{~mol} / \mathrm{L} \mathrm{HCl}$. Most of the $\mathrm{CN}-\mathrm{Cbl}$ derivatives were converted to the respective $\mathrm{OH}-\mathrm{Cbl}$ derivatives. After the formed $\mathrm{OH}-\mathrm{B}_{12}$ derivatives were desalted with a Sep-pak Vac 20 cc (5 g) C18 cartridge (Waters Corp.), they were separated from the remaining $\mathrm{CN}-\mathrm{Cbl}$ derivatives with silica gel 60 TLC under the same conditions as described above. After the TLC sheet had been dried, each $\mathrm{OH}-\mathrm{Cbl}$ derivative was collected, extracted with $80 \%(\mathrm{v} / \mathrm{v})$ methanol solution, evaporated to dryness under the reduced pressure.

\subsection{Cell Culture}

COS-7 (African green monkey kidney) cells were cultured in $10 \mathrm{~mL}$ Dulbecco's modified Eagle's medium, containing $10 \%$ (v/v) fetal bovine serum, penicillin (100 units $/ \mathrm{mL})$ and streptomycin $(100 \mu \mathrm{g} / \mathrm{mL})$, on a $100 \mathrm{~mm}$ dish at $37^{\circ} \mathrm{C}$ in a humidified $5 \% \mathrm{CO}_{2}-95 \%$ air $(\mathrm{v} / \mathrm{v})$ atmosphere. Authentic $\mathrm{OH}-\mathrm{Cbl}$ was added into the medium at a varied concentration $(0,0.1$, and $1.0 \mu \mathrm{mol} / \mathrm{L})$ in the presence or absence of $1.0 \mu \mathrm{mol} / \mathrm{L}$ alkylamine and $c$-lactam derivatives of $\mathrm{OH}$-Cbl. After reaching confluence, the cells were harvested and homogenised in 100 $\mathrm{mmol} / \mathrm{L}$ potassium phosphate buffer $(\mathrm{pH} 7.0)$, containing leupeptin $(1 \mathrm{mg} / \mathrm{mL})$, aprotinin $(10 \mathrm{mg} / \mathrm{mL})$ and 0.1 $\mathrm{mmol} / \mathrm{L}$ 4-(2-aminoethyl)-benzenesulfonyl fluoride, with a Teflon homogenizer at $4^{\circ} \mathrm{C}$. The homogenate was centrifuged at $10,000 \times \mathrm{g}$ for $10 \mathrm{~min}$ at $4^{\circ} \mathrm{C}$, and the supernatant fraction obtained was used as a crude enzyme solution for the enzyme assay.

\subsection{Enzyme Assay}

Methylamlonyl-CoA mutase (MCM) and methionine synthase (MS) activities were assayed by HPLC methods 
described previously [12] [13]. Total (holoenzyme and apoenzyme) and holo enzyme activities were determined in the presence or absence of each Cbl cofactor (MCM for 5'-deoxyadenosylcobalamin and MS for methylcobalamin).

\subsection{Western Blotting}

The cell homogenate described above was subjected to SDS-PAGE. Proteins in the gel were electroblotted to a polyvinylidene difluoride membrane. The membrane was treated with an anti-MS antibody, and immunoreactive proteins on the membrane were detected by a chemiluminescent method using a commercial kit (Super Signal West Pico Chemiluminescent substrate system; Pierce, Rockford, IL, USA) with horseradish peroxidase-conjugated goat anti-rabbit IgG antibodies. Digital images were obtained with a luminescent image analyzer (LAS-1000 Plus; Fuji Film, Tokyo, Japan).

\subsection{Statistical Analyses}

Total- and holo-MCM and MS activities of the COS-7 cells treated with or without the alkylamine derivatives of $\mathrm{OH}-\mathrm{Cbl}$ and $\mathrm{OH}-\mathrm{Cbl}$ [c-lactam] were statistically analyzed by one-way ANOVA, and post hoc analyses were done by the Tukey's multi-comparison test. These analyses were performed with GraphPad Prism ${ }^{\circledR}$ for windows version 5.03 (GraphPad Software Inc., La Jolla, CA 92037 USA). All data are expressed as means and standard deviations, and statistical significance is defined as $p<0.05$.

\section{Results and Discussion}

\subsection{Effects of Three Alkylamine Derivatives of $\mathrm{OH}-\mathrm{B}_{12}$ on MCM and MS Activities of COS-7 Cells}

The prepared alkylamine [hexylamine (1), dodecylamine (2), and hexadecylamine (3) in Figure 2] derivatives of OH-Cbl $(1.0 \mu \mathrm{mol} / \mathrm{L})$ were evaluated as Cbl-dependent enzyme inhibitors in total and holo-MCM and MS activities of the COS-7 cells grown in $0.1 \mathrm{mmol} / \mathrm{L} \mathrm{OH-Cbl-supplemented} \mathrm{medium} \mathrm{(Figure} \mathrm{3).} \mathrm{All} \mathrm{alkylamine} \mathrm{de-}$ rivatives did not affect the enzyme activity of total MCM (holo- and apo-enzymes), but significantly inhibited the enzyme activity of the holo-MCM. While the addition of each alkylamine derivative showed the same degrees of inhibition in the enzyme activities of both total and holo-MS. The dodecylamine and hexadecylamine derivatives are stronger inhibitors in both holo-enzymes (about 30\% and 45\% activities of MCM and MS of the control cells, respectively) than the hexylamine derivative. All alkylamine derivatives used did not show any cytotoxicity in the cultured COS-7 under the experimental conditions.

McEwan et al. [10] have demonstrated that the dodecylamine derivative of Cbl can bind IF considerably (36\% of intact $\mathrm{Cbl}$ ), but hexadecylamine derivative cannot. We selected the $\mathrm{OH}-\mathrm{Cbl}$ dodecylamine derivative for further experiments.

\subsection{Effect of the $\mathrm{OH}-\mathrm{Cbl}$ Dodecylamine Derivative and $\mathrm{OH}-\mathrm{Cbl}$ [c-Lactam] on MCM Activity of COS-7 Cells}

We evaluated effects of the dodecylamine derivative of $\mathrm{OH}-\mathrm{Cbl}(1.0 \mu \mathrm{mol} / \mathrm{L})$ on total and holo-MCM activities of the cells grown in $\mathrm{OH}-\mathrm{Cbl}$ (at $0,0.1$, and $1.0 \mu \mathrm{mol} / \mathrm{L}$ )-supplemented medium, compared with the $\mathrm{OH}-\mathrm{Cbl}$ [c-lactam] that is known as the Cbl-dependent enzyme inhibitor [8] [9]. When total MCM activity was significantly decreased with increase in concentration of the added $\mathrm{OH}-\mathrm{Cbl}, 1.0 \mu \mathrm{mol} / \mathrm{L}$ dodecylamine and $c$-lactam derivatives did not affect the total enzyme activity at each concentration of authentic OH-Cbl (Figure 4). The dodecylamine and $c$-lactam derivatives of $\mathrm{OH}$-Cbl, however, inhibited significantly the holo-MCM activity (about $60 \%$ activity of the control) in the presence of $0.1 \mu \mathrm{mmol} / \mathrm{L}$ authentic $\mathrm{OH}-\mathrm{Cbl}$. Although the dodecylamine derivative did not affect any holo-MCM activity in the presence of $1.0 \mu \mathrm{mmol} / \mathrm{L}$ authentic OH-Cbl, OH-Cbl [c-lactam] could inhibit about $17 \%$ of the holo-enzyme activity.

\subsection{Effect of the OH-Cbl Dodecylamine Derivative and OH-Cbl [c-Lactam] on MS Activity of COS-7 Cells}

One $\mu \mathrm{mol} / \mathrm{L}$ dodecylamine derivative could inhibit significantly both total and holo-MS enzyme activities (about 
(a)

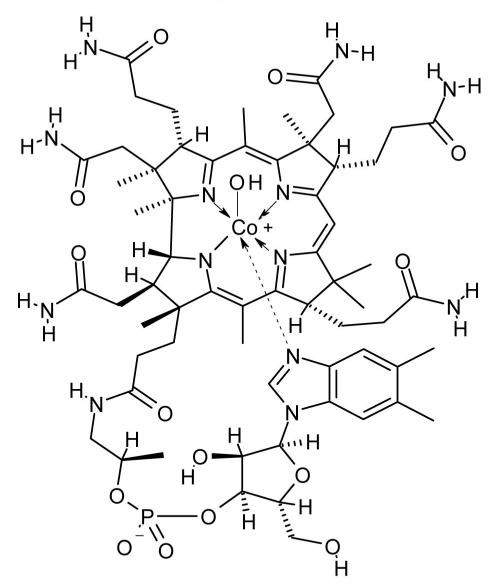

(b)

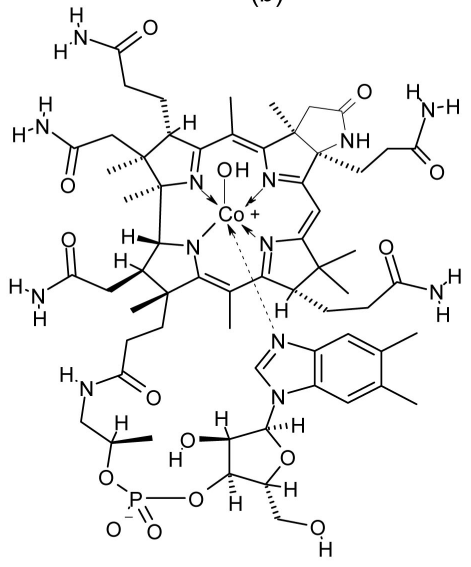

(c)

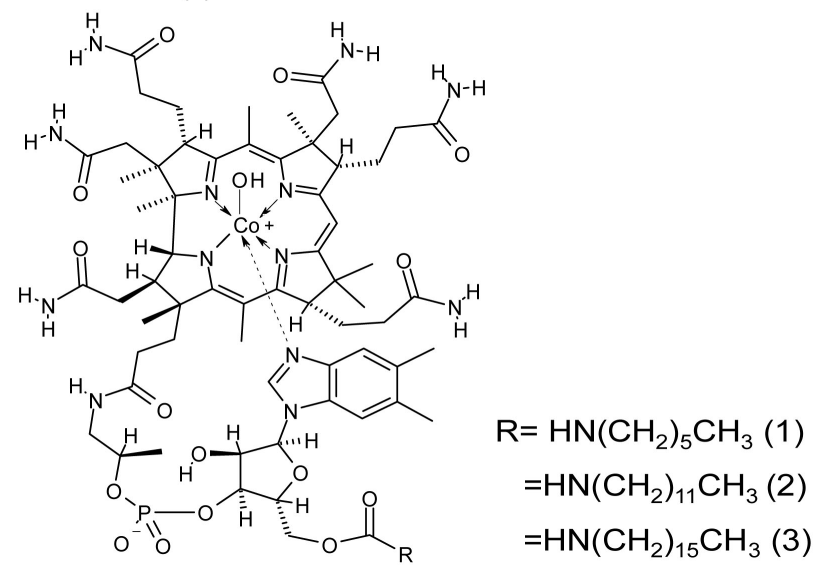

Figure 2. Structural formula of alkylamine and $c$-lactam derivatives of $\mathrm{OH}$-Cbl used in this study. (a) $\mathrm{OH}-\mathrm{Cbl}$; (b) OH-Cbl [c-lactam]; and (c) Hexylamine (1), dodecylamine (2), and hexadecylamine (3) derivatives of $\mathrm{OH}-\mathrm{Cbl}$.

$47 \%$ and $45 \%$ activity of the control, respectively, in the presence of $1.0 \mu \mathrm{mol} / \mathrm{L} \mathrm{OH}-\mathrm{Cbl}$ ), while $\mathrm{OH}-\mathrm{Cbl}$ [c-lactam] did not inhibit both total and holo-enzyme activities of the cells grown in the presence of $1.0 \mu \mathrm{mol} / \mathrm{L}$ $\mathrm{OH}-\mathrm{Cbl}$. Most MS has been reported to exist as the holo-enzyme in mammalian cells [14] (Figure 5). Although we have no information available on the mechanism of inhibition of MS by the OH-Cbl dodecylamine derivative, it is possible that the $\mathrm{OH}-\mathrm{Cbl}$ derivative competitively inhibits MS.

\subsection{Western Blot Analysis of MS Protein in the Cell Homogenates of the COS-7 Treated with or without Various Concentration of the $\mathrm{OH}-\mathrm{Cbl}$ Dodecylamine Derivative}

For further elucidation of the decrease in the MS activity in the dodecylamine derivative-treated cells, MS protein expression was examined by SDS-PAGE followed by immunobloting with an antibody of human MS. As shown in Figure 6, the expression level of MS protein was significantly increased with dose-dependent manner by the addition of authentic $\mathrm{OH}-\mathrm{Cbl}$. The dodecylamine derivative could hardly affect the MS protein levels at each $\mathrm{OH}-\mathrm{Cbl}$ concentration, indicating that the dodecylamine derivative could not inhibit the MS protein level, but inhibit MS enzyme activity. These results indicate that the dodecylamine derivative of OH-Cbl acts as a potent inhibitor of the Cbl-dependent MS, the key enzyme involved in various methylation reaction (DNA, phospholipids, and so on) via S-adenosylmethionine [15]. Since the OH-Cbl dodecylamine derivative is simply prepared over considerably high yield ( 50\%) relative to $\mathrm{OH}-\mathrm{Cbl}$ [c-lactam], the dodecylamine derivative would be 
(a)

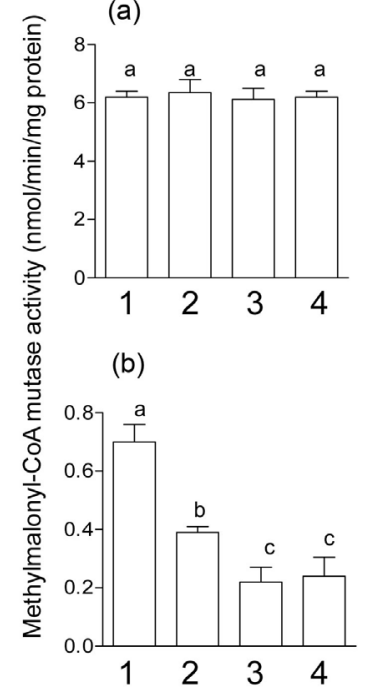

(c)

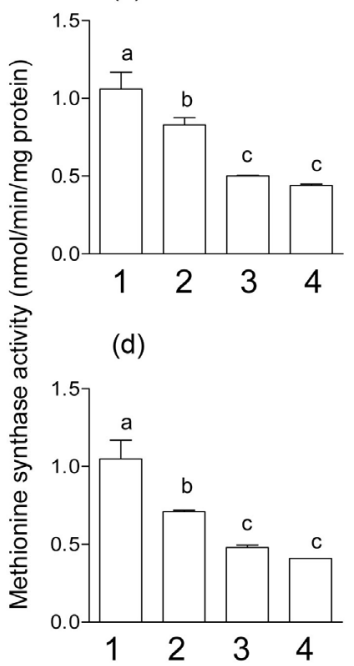

Figure 3. Effects of the addition of three alkylamine derivatives of $\mathrm{OH}-\mathrm{Cbl}$ on $\mathrm{MCM}$ and MS activities of COS-7 cells. (a) Total MCM activity; (b) Holo-MCM activity; (c) Total MS activity, and (d) Holo-MS activity. These enzyme activities were assayed in the cell homogenates of COS-7 treated with none (1) and hexylamine (2), dodecylamine (3), and hexadecylamine (4) derivatives of $\mathrm{OH}-\mathrm{Cbl}(1.0 \mu \mathrm{mol} / \mathrm{L})$ in the presence of authentic $\mathrm{OH}-\mathrm{Cbl}(0.1 \mu \mathrm{mol} / \mathrm{L})$. Values are the means of three dishes, with standard deviations represented by vertical bars. ${ }^{\mathrm{abc}}$ Values with unlike letters were significantly different $(p<0.05)$.

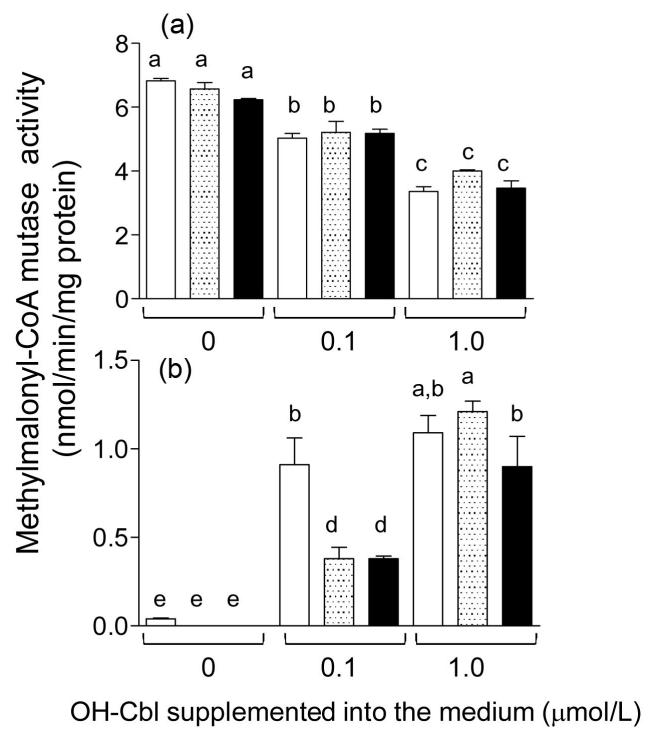

Figure 4. Effects of the addition of dodecylamine and c-lactam derivatives of OH-Cbl on MCM activity of COS-7 cells. Total (a) and holo- (b) MCM activities were assayed in the cell homogenates of COS-7 treated with none $(\square), 1.0 \mu \mathrm{mol} / \mathrm{L} \mathrm{OH}-\mathrm{Cbl}$ dodecylamine derivative( ), and $\mathrm{OH}-\mathrm{Cbl}$ [c-lactam] ( $\boldsymbol{\square})$ in the presence of the indicated authentic $\mathrm{OH}-\mathrm{Cbl}$. Values are the means of three dishes, with standard deviations represented by vertical bars. ${ }^{\text {abcde }}$ Values with unlike letters were significantly different $(p<0.05)$.

a useful tool to prepare Cbl-deficient mammalian cells and to elucidate the metabolic disorders caused by the reduced enzyme activity of MS which exerts an important influence on the cellular metabolisms. Moreover, Cbl dodecylamine derivative shows high affinity binding of IF [10], suggesting that Cbl deficiency in mammals may be readily induced by oral or intravenous administration of this compound. 


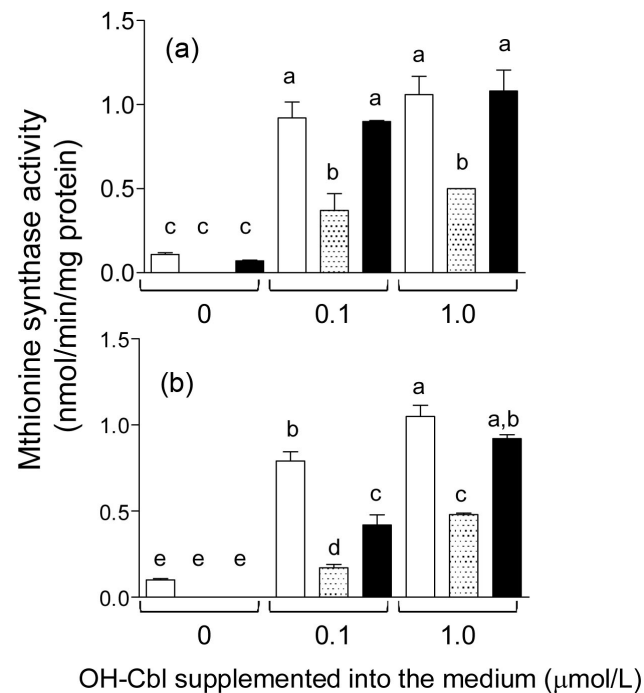

Figure 5. Effects of the addition of dodecylamine and c-lactam derivatives of $\mathrm{OH}-\mathrm{Cbl}$ on MS activity of COS-7 cells. Total (a) and holo- (b) MS activities were assayed in the cell homogenates of COS-7 treated with none $(\square), 1.0 \mu \mathrm{mol} / \mathrm{L} \mathrm{OH}-\mathrm{Cbl}$ dodecylamine derivative (2), and $\mathrm{OH}-\mathrm{Cbl}$ [c-lactam] ( $\square$ ) in the presence of the indicated concentrations of authentic $\mathrm{OH}-\mathrm{Cbl}$. Values are the means of three dishes, with standard deviations represented by vertical bars. ${ }^{\text {abcde }}$ Values with unlike letters were significantly different $(p<0.05)$.

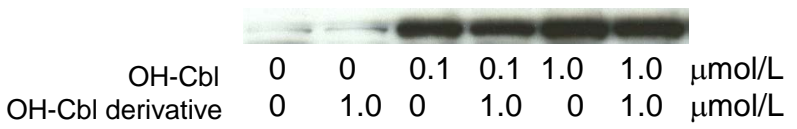

Figure 6. Western blot analysis of MS protein in the cell homogenates of COS-7 treated with or without $1.0 \mu \mathrm{mol} / \mathrm{L} \mathrm{OH}-\mathrm{Cbl}$ dodecylamine derivative in the presence of the indicated concentrations of authentic OH-Cbl. Data are typical immunoreactive patterns of the MS protein from three independent western blot analyses of the treated COS-7 cells.

\section{Acknowledgements}

This work was supported in part by JSPS KAKENHI Grant Number 20580132 (F.W.) and 265387 (T.B.) from the Ministry of Education, Culture, Sports, Science and Technology, Japan.

\section{References}

[1] Alpers, D.H. and Russell-Jones, G.I. (1999) Intrinsic Factor, Haptocorrin, and Their Receptors. In: Banerjee, R., Ed., Chemistry and Biochemistry of Vitamin $B_{12}$, John Wiley \& Sons, New York, 411-439.

[2] Rothenberg, S.P., Quadros, E.V. and Regec, A. (1999) Transcobalamin II. In: Banerjee, R., Ed., Chemistry and Biochemistry of Vitamin $B_{12}$, John Wiley \& Sons, New York, 441-473.

[3] Barnerjee, R. (2001) Radical Peregrinations Catalyzed by Coenzyme B ${ }_{12}$-Dependent Enzymes. Biochemistry, 40, 61916198. http://dx.doi.org/10.1021/bi0104423

[4] Toohey, J.I. (2006) Vitamin $\mathrm{B}_{12}$ and Methionine Synthesis: A Critical Review. Is Nature's Most Beautiful Cofactor Misunderstood? BioFactors, 26, 45-57. http://dx.doi.org/10.1002/biof.5520260105

[5] Institute of Medicine (1998) Vitamin $B_{12}$. In: Dietary Reference Intakes for Thiamin, Riboflavin, Niacin, Vitamin B, Folate, Vitamin $B_{12}$, Pantothenic Acid, Biotin, and Choline, Institute of Medicine, National Academy Press, Washington DC, 306-356.

[6] O’Leary, F. and Samman, S. (2010) Vitamin $B_{12}$ in Health and Disease. Nutrients, 2, 299-316. http://dx.doi.org/10.3390/nu2030299

[7] Toyoshima, S., Watanabe, F., Saido, H., Pezacka, E., Jacobsen, D.W., Miyatake, K. and Nakano, Y. (1996) Accumulation of Methylmalonic Acid Caused by Vitamin $B_{12}$-Deficiency Disrupts Normal Cellular Metabolism in Rat Liver. British Journal of Nutrition, 75, 929-938. http://dx.doi.org/10.1079/BJN19960198 
[8] Matthews, J.H. (1997) Cyanocobalamin [c-Lactam] Inhibits Vitamin B 12 and Causes Cytotoxicity in HL60 Cells: Methionine Protects Cells Completely. Blood, 89, 4600-4607.

[9] Stabler, S.P., Brass, E.P., Marcell, P.D. and Allen, R.H. (1991) Inhibition of Cobalamin-Dependent Enzymes by Cobalamin Analogues in Rats. Journal of Clinical Investigation, 87, 1422-1430. http://dx.doi.org/10.1172/JCI115148

[10] McEwan, J.F., Veitch, H.S. and Russell-Jones, G.J. (1999) Synthesis and Biological Activity of Ribose-5'-Carbamate Derivatives of Vitamin $B_{12}$. Bioconjugate Chemistry, 10, 1131-1136. http://dx.doi.org/10.1021/bc990086p

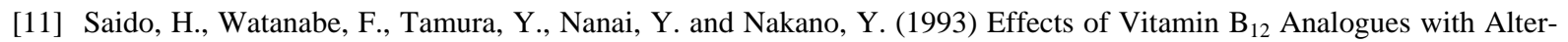
nation in the Side Chains of the Corrin Ring on Urinary Methylmalonate Excreation in Vitamin $B_{12}$-Deficient Rats. Bioscience, Biotechnology, and Biochemistry, 57, 607-610. http://dx.doi.org/10.1271/bbb.57.607

[12] Miyamoto, E., Tanioka, Y., Nishizawa-Yokoi, A., Yabuta, Y., Ohnishi, K., Nisono, H., Shigeoka, S., Nakano, Y. and Watanabe, F. (2010) Characterization of Methylmalonyl-CoA Mutase Involved in the Propionate Photoassimilation of Euglena gracilis Z. Archives of Microbiology, 192, 437-446. http://dx.doi.org/10.1007/s00203-010-0572-X

[13] Tanioka, Y., Yabuta, Y., Yamaji, R., Shigeoka, S., Nakano, Y., Watanabe, F. and Inui, H. (2009) Occurrence of Pseudovitamin $\mathrm{B}_{12}$ and Its Possible Function as the Cofactor of Cobalamin-Dependent Methionine Synthase in a Cyanobacterium Synechocysitis sp. PCC6803. Journal of Nutritional Science and Vitaminology, 55, 518-521. http://dx.doi.org/10.3177/jnsv.55.518

[14] Chen, Z., Chakraborty, S. and Banerjee, B. (1995) Demonstration That Mammalian Methionine Synthases Are Predominantly Cobalamin-Loaded. Journal of Biological Chemistry, 270, 19246-19249. http://dx.doi.org/10.1074/jbc.270.33.19246

[15] Waly, W., Olteanu, H., Banerjee, R., Choi, S.W., Mason, J.B., Parker, B.S., Sukumar, S., Shim, S., Sharma, A., Benzecry, J.M., Power-Charnitsky, V.A. and Deth, R.C. (2004) Activation of Methionine Synthase by Insulin-Like Growth Factor-1 and Dopamine: A Target for Neurodevelopmental Toxins and Thimerosal. Molecular Psychiatry, 9, 358-370. http://dx.doi.org/10.1038/sj.mp.4001476 
Scientific Research Publishing (SCIRP) is one of the largest Open Access journal publishers. It is currently publishing more than 200 open access, online, peer-reviewed journals covering a wide range of academic disciplines. SCIRP serves the worldwide academic communities and contributes to the progress and application of science with its publication.

Other selected journals from SCIRP are listed as below. Submit your manuscript to us via either submit@scirp.org or Online Submission Portal.
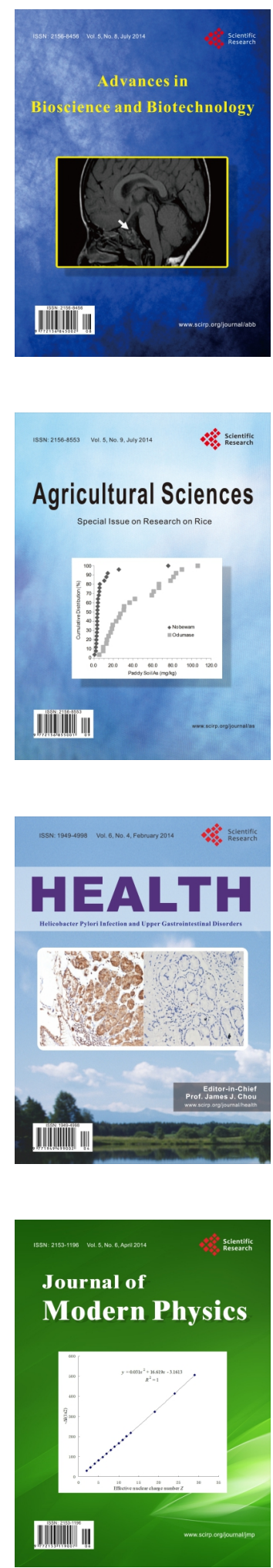
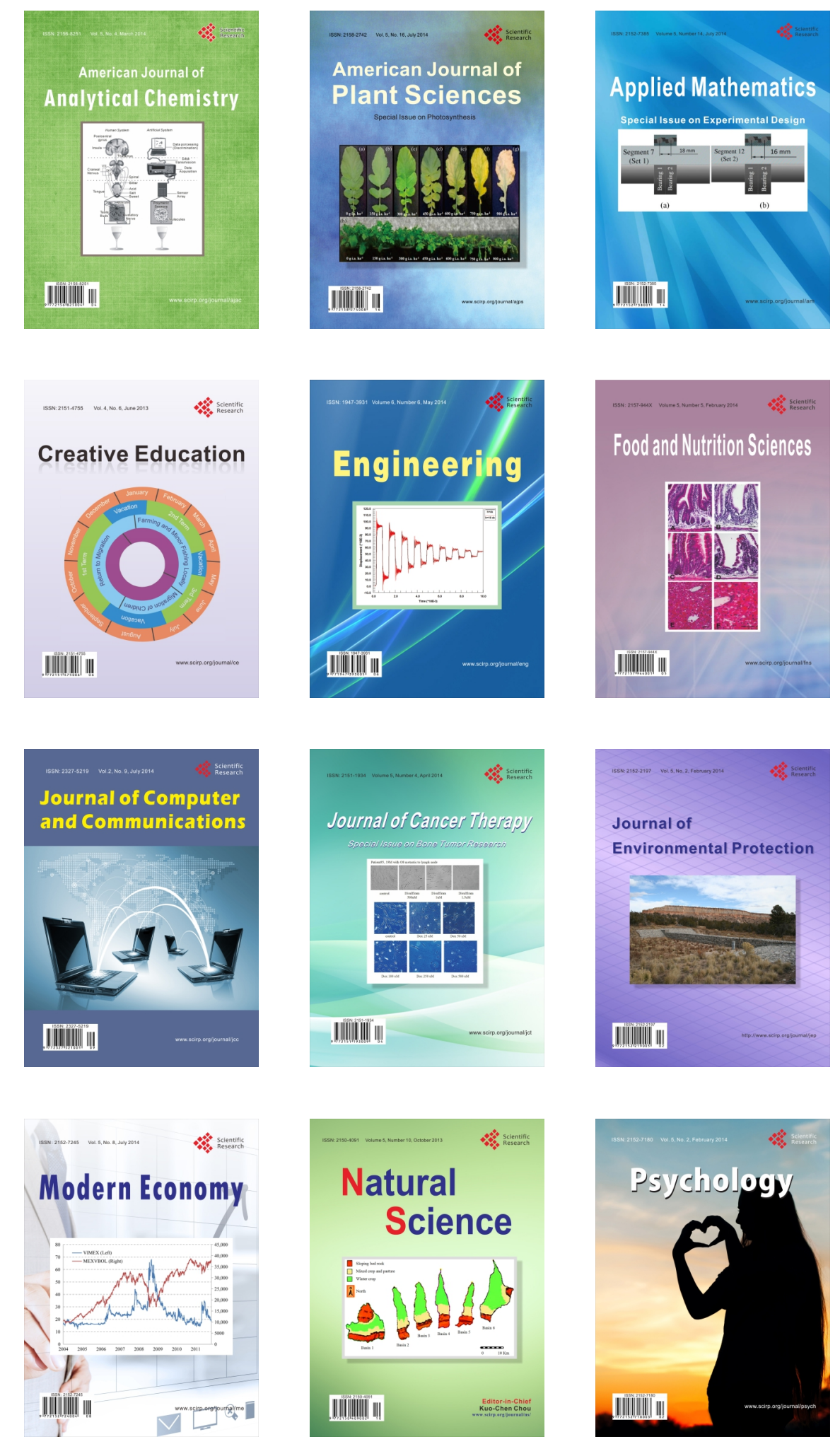